1 Clinical trials and clinical practice. Lancet 1993;342:877-8.

2 North of England Stable Angina Development Group. North of England evidence based guidelines development project: summary version of evidence based guideline for the primary care management of stable angina. BMF 1996;312:827-32

3 Thompson R, Lavender M, Madhok R. How to ensure that guidelines are effective. BM7 1995;311:237-42

4 The Task Force on Heart Failure of the European Society of Cardiology.
Guidelines for the diagnosis of heart failure. Eur Heart $\mathcal{f}$ 1995;16: 741-51.

Department of Health. Working for Patients. Working Paper 6. London: HMSO Publications, 1989.

6 de Lacey G. What is audit? Why should we be doing it? Hospital Update 1992;18:458-66.

7 Fox $\mathrm{K}$, O'Malley $\mathrm{C}$. Involving junior doctors in audit. Hospital Update 1994;20:254-5.

\title{
STAMPS IN CARDIOLOGY
}

\section{Sir William Osler (1849-1919)}

Sir William Osler is depicted on the 6 cent Canadian stamp issued in 1969 to commemorate the 50th anniversary of his death. The stamp printed by the British American Bank Note Company is inscribed with the words "The System of Medicine" and "Traité de Médecine".

William Osler was born in Ontario, Canada of Cornish parents and became a professor of medicine at his alma mater McGill University at the age of 25. At the Montreal General Hospital he was also the pathologist and his large personal experience of autopsies laid the foundation of his subsequent brilliant career as a clinician. His reputation soon spread and it led to his election as a Fellow of the Royal College of Physicians of London at age 34, only the third Canadian to be elected to the fellowship, and to the distinction of being the Goulstonian Lecturer-his title was "Malignant Endocarditis". He wrote an important monograph on Angina Pectoris and Related Diseases, and in his Lumleian Lectures at the college in 1910 on that subject he mentioned coronary artery spasm as a possible cause. In 1889 he became physician in chief at the newly founded Johns Hopkins Hospital in Baltimore, where he wrote his famous textbook The Principles and Practice of Medicine, probably the last of its kind to be written by a single author. His emphasis on the paucity of effective treatment for many diseases came to the notice of $\mathrm{Mr}$ John D Rockefeller and led to the founding of the Rockefeller Institute. In 1904 he was appointed Regius Professor of Medicine at Oxford and he was foremost in the foundation of the Association of Physicians of Great Britain and Ireland and of the Quarterly fournal of Medicine. His seven volume System of Medicine, referred to on the stamp, was completed in 1908 . He wrote many papers on cardiological subjects, including a classic one on bicuspid aortic valve and he encouraged Maude Abbott to produce her

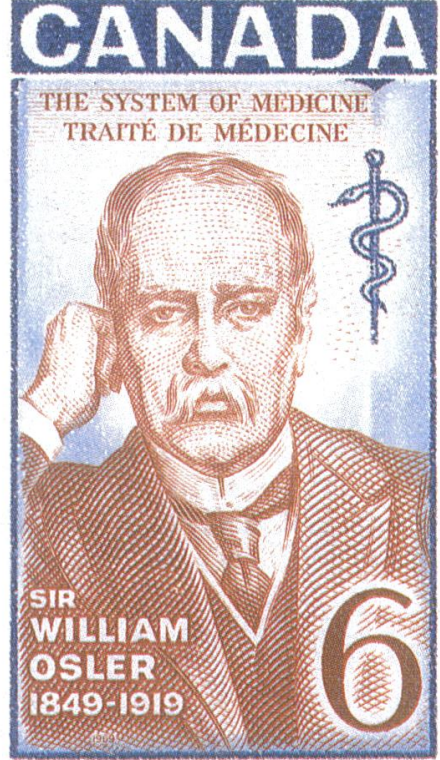

renowned Atlas of Congenital Heart Disease. He is known eponymously for Osler's nodes, Osler-Rendu-Weber syndrome and Vaquez-Osler disease. His scholarship in medical history, and deep affection for his memory, are perpetuated by the American Osler Society and the Osler Club of London, and his fine collection of old books forms the Bibliotheca Osleriana at McGill. William Osler is still widely remembered as a great physician and humanist, and notably for his encouragement of young doctors. His house in Oxford was known as "The Open Arms". 